\title{
ДОСЛІДЖЕННЯ ВПЛИВУ ХІМІЧНИХ ВЛАСТИВОСТЕЙ АКТИВНИХ БАРВНИКІВ НА ПРОЦЕС ФОТОДЕСТРУКЦІЇ ЗАБАРВЛЕНЬ БАВОВНЯНИХ ТРИКОТАЖНИХ ПОЛОТЕН
}

На сьогодні активні барвники є найпопулярнішим класом, який використовують для отримання гладкофарбованих бавовняних текстильних матеріалів, $i$ єдиним для бавовняного трикотажу. Отримані забарвлення активними барвниками відрізняються високою стійкістю до прання внаслідок утворення ковалентного зв'язку барвника з полімером. У зв'язку з появою нових класів бі- та поліфункціональних активних барвників актуальним є питання щуодо встановлення закономірностей впливу їх хімічної будови на світлостійкість отриманих забарвлень.

Мета роботи полягає дослідженні впливу хімічних властивостей активних барвників, а саме: хімічної структури хромофору, кількості та типу активних груп - на світлостійкість отриманих на бавовняному трикотажі забарвлень.

Досліджування здійснювалось з використанням бавовняного трикотажного полотна, яке було підготовлене відповідним способом. Фарбування текстильного матеріалу здійснювалось 3 використанням моно-, бі- та поліфункціональних барвників за відповідними режимами. Досліджувані барвники за хімічною структурую були азо- та дисазобарвниками, антрахіноновими, фталочіаніновими та формазановими барвниками. За хімічною будовою хромофору - монохлортриазиновими, дихлортриазиновими, вінілсульфоновими та біфункціональними 3 монохлортриазиновою вінілсульфоновою активною групою.

Для отриманих зразків трикотажу було досліджено кінетику фотодеструкиіі забарвлень. Інсоляцію зразків здійснювали на приладі з ртутно-вольфрамовою лампою RF 1201 BS («REFOND») 3 періодичним визначенням колірних відмінностей забарвлень за допомогою колориметра PCE-TCR 200.

У роботі наведені результати дослідження залежності світлостійкості зразків забарвленого бавовняного трикотажу від хімічних властивостей активних барвників. Встановлено хімічний клас барвників, щуо мають найнижчу стійкість до дї світла в порівняння з іншими досліджуваними хромофорними системами. Крім того, знайдено залежність світлостійкості забарвлень на бавовняному трикотажі від хімічної будови та кількості активних груп.

Ключові слова: бавовняний трикотаж, активні барвники, хромофор, активна група, світлостійкість, кінетика фотодеструкиії забарвлень.

О.Я. СЕМЕШКО Херсонский национальный технический университет ORCID: 0000-0002-8309-5273

Т.С. АСАУЛЮК Херсонский национальный технический университет ORCID: 0000-0001-5961-6895 Ю.Г. САРИБЕКОВА Херсонский национальный технический университет ORCID: 0000-0001-6430-6509

\section{ИССЛЕДОВАНИЕ ВЛИЯНИЯ ХИМИЧЕСКИХ СВОЙСТВ АКТИВНЫХ КРАСИТЕЛЕЙ НА ПРОЦЕСС ФОТОДЕСТРУКЦИИ ОКРАВЛЕННЫХ ТРИКОТАЖНЫХ ПОЛОТЕН}

На сегодняшний день активные красители являются самым популярным классом, который используют для получения гладкокрашеных хлопчатобумажных текстильных материалов, $и$ единственным для хлопкового трикотажа. Окраски, полученные активныли красителями, отличаются высокой стойкостью к стирке вследствие образования ковалентной связи красителя с полимером. В 
связи с появлением новых классов би- и полифункииональных активных красителей актуальнылм является вопрос установления закономерностей влияния их химического строения на светостойкость полученных окрасок.

Цель работы состоит в исследовании влияния химических свойств активных красителей, а именно: химической структуры хромофора, количества и типа активных групп - на светостойкость полученных на хлопчатобумажном трикотаже окрасок.

Исследование осуществлялось с использованием хлопчатобумажного трикотажного полотна, подготовленного соответствующим способом. Окрашивание текстильного материала производилось с использованием моно-, би- и полифункииональных красителей по соответствующим режимам. Исследуемье красители по химической структуре являлись азо- и дисазокрасителями, антрахиноновыми, фталочианиновыми и формазановыми красителями. По химическому строению хромофора - монохлортриазиновыми, дихлортриазиновыми, винилсульфоновыми и бифункииональными с монохлортриазиновой / винилсульфоновой активной группой.

Для полученных образиов трикотажа была исследована кинетика фотодеструкции окрасок. Инсоляциию образцов осуществляли на приборе с ртутно-вольфрамовой лампой RF 1201 BS («REFOND») с периодическим определением ияветовых отличий окрасок с помощзюю колориметра PCE-TCR 200.

В работе приведень результатьл исследования зависимости светостойкости образиов окрашенного хлопчатобумажного трикотажа от химических свойств активных красителей. Установлен химический класс красителей, имеющих низкую устойчивость к воздействию света по сравнению с другими исследуемыми хромофорными системами. Кроме того, найдена зависимость светостойкости окрасок на хлопчатобумажном трикотаже от химического строения и количества активных групп.

Ключевые слова: хлопчатобумажный трикотаж, активные красители, хромофор, активная группа, светостойкость, кинетика фотодеструкции окрасок.

O.Ya. SEMESHKO Kherson National Technical University ORCID: htt0000-0002-8309-5273

T.S. ASAULYUK

Kherson National Technical University ORCID: 0000-0001-5961-6895 Yu.G. SARIBYEKOVA Kherson National Technical University ORCID: 0000-0001-6430-6509

\section{STUDY OF THE INFLUENCE OF REACTIVE DYES CHEMICAL PROPERTIES ON THE PROCESS OF DYED KNITTED FABRICS PHOTODESTRUCTION}

Today, reactive dyes are the most popular class used to obtain dyed cotton textile materials, and the only one for cotton knitwear. Colours obtained with reactive dyes are highly resistant to washing due to the formation of a covalent bond of the dye with the polymer. In connection with the emergence of new classes of biand polyfunctional reactive dyes, it is urgent to establish the regularities of the influence of their chemical structure on the lightfastness of the obtained colours.

The aim of the work is to study the influence of chemical properties of reactive dyes, namely the chemical structure of chromophore, the number and type of active groups, on the lightfastness of colours obtained on cotton knitted fabrics.

The study was carried out using a cotton knitted fabric prepared in an appropriate way. The dyeing of the textile material was carried out using mono-, bi-and polyfunctional dyes in the appropriate modes. In terms of chemical structure, the dyes under study were azo and disazo dyes, anthraquinone, phthalocyanine, and formazan dyes. According to the chromophore chemical structure the studied dyes were monochlorotriazine, dichlorotriazine, vinyl sulfonic and bifunctional with a monochlorotriazine / vinyl sulfone active group.

For the obtained knitted fabric samples, the kinetics of colours photodestruction was investigated. Insolation of the samples was carried out on the RF 1201 BS (REFOND) device with a mercury-tungsten lamp with periodic determination of samples colour differences using a PCE-TCR 200 colorimeter.

The article presents the results of a study of the dependence of dyed cotton knitted fabric samples lightfastness on the chemical properties of reactive dyes. The chemical class of dyes has been established, which have low resistance to light in comparison with other investigated chromophore systems. In addition, the dependence of the cotton knitted fabric colours lightfastness on the chemical structure and the number of active groups was found. 
Keywords: cotton knitted fabric, reactive dyes, chromophore, active group, lightfastness, kinetics of dyes photodestruction.

\section{Постановка проблеми}

Активні барвники є головним класом для отримання гладкофарбованих бавовняних волокнистих матеріалів - тканин і трикотажних полотен. Вони $€$ першим класом барвників, які здатні утворювати хімічні ковалентні зв'язки 3 волокном. Загальну формулу активних барвників можна записати як $\mathrm{A}-\mathrm{Xp}-\left(\mathrm{SO}_{3} \mathrm{Na}\right)_{\mathrm{n}}$, де $\mathrm{A}$ - активний центр, $\mathrm{Xp}$ - хромофор, що визначає колір барвника, $\left(\mathrm{SO}_{3} \mathrm{Na}\right)_{\mathrm{n}}-$ групи, що надають барвнику розчинності. Крім того, молекулам активних барвників розчинності у воді надають також карбоксильні і сульфоетерні групи. Число цих груп визначається величиною молекули барвника.

Будова хромофорної системи молекул активних барвників визначає такі властивості, як колір, стійкість забарвлення до дії світла, спорідненість до субстрату, розчинність у воді, дифузійну здатність; а будова активної системи - реакційну здатність, стабільність зв'язку барвник - волокно, стійкість барвника у фарбувальних розчинах і друкованих фарбах. Безумовно, на ряд властивостей, які визначаються будовою хромофорної системи, впливає активна система, i навпаки, барвники з однією $\mathrm{i}$ тією ж активною групою в залежності від будови можуть мати різну реакційну здатність [1]. Для активних барвників використовують хромофорні групи, що $є$ характерними для кислотних та інших класів барвників: моноазо-, дисазо-, антрахінонові, фталоціанінові та інші $[2,3]$.

Забарвлення, отримані активними барвниками, відрізняються високою стійкістю до прання внаслідок утворення ковалентного зв'язку барвника 3 полімером. У зв'язку з появою нових класів бі- та поліфункціональних активних барвників актуальним $є$ питання щодо встановлення закономірностей впливу їх хімічної будови на світлостійкість отриманих забарвлень.

\section{Аналіз останніх досліджень і публікацій}

Активний центр - це частина молекули барвника, що містить реакційноздатний активний атом карбону і групи, які забезпечують його активність в реакціях з волокном. На сьогодні відомо близько 200 активних груп, які забезпечують хімічний зв'язок хромофора 3 волокном [3, 4]. В залежності від кількості активних груп активні барвники бувають моно-, бі- та поліфункціональними.

Цінність активної групи у молекулах активних барвників, крім міцного зв'язування з волокном, полягає у меншій залежності результатів фарбування від спорідненості барвника до субстрату як, наприклад, у випадку з прямими барвниками. Це дозволило використовувати для синтезу активних барвників простіші за будовою структури 3 широким вибором хромофорних систем, які забезпечують більш яскраві кольори забарвлень і глибоке профарбовування волокна.

Активні барвники вступають в хімічну реакцію 3 целюлозним волокном 3 утворенням ковалентного зв'язку за двома видами механізмів [5-7], а саме:

1) шляхом реакції нуклеофільного заміщення $\mathrm{S}_{\mathrm{N}}$ за схемою:

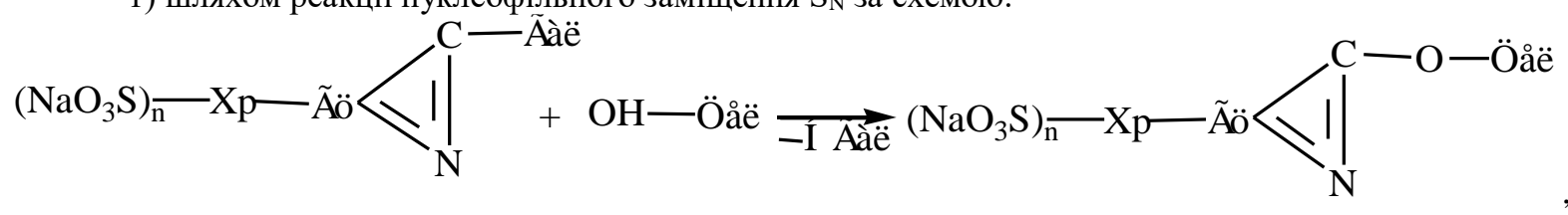

де Гц - гетероцикл;

Гал - галоген;

2) шляхом реакції нуклеофільного приєднання $\mathrm{A}_{\mathrm{N}}$ за схемою:

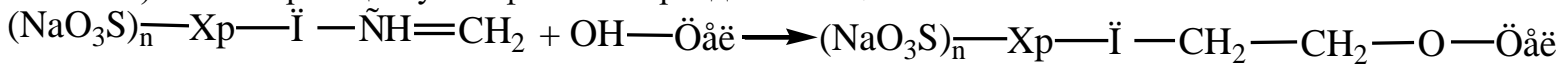

де П - полярна група - $\mathrm{NHCO}-,-\mathrm{SO}_{2}-\mathrm{NH}-,-\mathrm{SO}_{2}-$.

Реакційна здатність активних барвників визначається величиною надлишкового позитивного заряду на атомі Карбону активного центру, який залежить, перш за все, від будови цього центру і в меншій мірі від будови хромофорної частини [5-7].

Висока реакційна здатність активних барвників із дихлортриазиновою реакційної групою пояснюється наявністю в триазині трьох електронегативних атомів Нітрогену i високою електроноакцепторністю хлору, що призводить до поляризації зв'язку і зменшення електронної густини на атомі Карбону. Це робить молекулу барвника здатною до реакції нуклеофільного заміщення. Електрофільний характер атомів вуглецю змінюється під електрохімічним впливом замісника, введеного в триазиновий гетероцикл, при цьому електроновідтягуючі групи збільшують реакційну здатність барвників. Такі групи, як ціаногрупа, також збільшують їх реакційну здатність, тоді як амінозаміщена, аміно-, алкокси- та інші групи знижують.

Реакційна здатність активних барвників 3 гетероциклічною активною системою може бути змінена шляхом заміни рухомого, здатного до відщеплення атома. Вона зростає в ряду $\mathrm{C} 1 \rightarrow \mathrm{SO}_{2} \mathrm{CH}_{3} \rightarrow \mathrm{F}$, тому, наприклад, монофтортриазинові барвники більш реакційноздатні, ніж монохлортриазинові 3 аналогічними структурами хромогенів [8], але менш реакційноздатні, ніж дихлортриазинові активні 
барвники [9]. На відміну від триазинового кільця інші гетероциклічні активні системи містять тільки два атома Нітрогену: вони мають високу електронну щільність біля атомів Карбону, тому реакційна здатність барвників на їх основі менша.

Реакційну здатність вінілсульфонових барвників можна змінювати шляхом введення груп, що зв'язують активну групу з хромогеном. Так реакційна здатність сульфонаміду нижче, ніж у сульфону, через дезактивуючу дію NH-групи [8].

За зменшенням реакційної здатності монофункціональні активні барвники розташовуються у наступній послідовності $[5,10]:$ дихлортриазинові $\rightarrow$ дифторхлорпиримідинові $\rightarrow$ монофтортриазинові $\rightarrow$ вінілсульфонові $\rightarrow$ монохлортриазинові. Реакційна здатність активних барвників залежить не тільки від типу активних груп і структури хромогену, але і від умов фарбування: $\mathrm{pH}$ середовища, температури, концентрації барвника і електроліту.

У якості хромофорів в активних барвниках від жовтого до чорного кольорів переважають азоструктури, що мають високі показники молярного коефіцієнта екстинкції. Колір зеленувато-жовтих азобарвників посилюється при безпосередній реакції азогрупи з 1-фенілпіразолоновим гетероциклом. Барвники темно-синіх і чорних кольорів можуть містити дві або більше азогрупи. Азобарвники червонокоричневих, бордових, фіолетових і ультрамаринових кольорів часто представляють собою комплекси Купруму 1:1 3 хромогеном. Молекули таких барвників характеризуються компланарністю i, внаслідок цього, високою спорідненістю до целюлозних волокон. Морські сині і коричневі барвники здебільшого за будовою є дисазоструктурами та мають високу спорідненість. Азобарвники сірих і чорних кольорів зазвичай $є$ сполуками комплексу 1:2 з іонами Кобальту та Хрому. Для таких барвників характерною $є$ низька спорідненість по відношенню до целюлози, і вони використовуються, головним чином, у поліграфії [11].

Серед яскравих синіх барвників домінують похідні антрахінону, незважаючи на їх невисоку поглинаючу здатність і значну вартість. Основною перевагою цих барвників $\epsilon$ високі показники стійкості забарвлень до дії світла і хімічних препаратів [12]. Антрахіноновими є також деякі синьо-зелені активні барвники. Також серед барвників синіх кольорів $є$ трифеноксазинові та мідні комплекси формазанових хромофорних структур [13].

Бірюзові барвники $є$ переважно фталоціанінами міді, а яскраві синьо-зелені - фталоціанінами нікелю. Основний недолік таких структур - низька дифузійна здатність, обумовлена великими розмірами молекул і яка призводить до невисокого ступеня їх використання в процесах колорування. Компанією «Dystar» (США) розроблені активні барвники на основі фталоціаніну алюмінію, які мають підвищену фарбувальну здатність, світлостійкість і $є$ більш екологічними, ніж нікель- і купрумвмісні барвники [14].

У молекулах деяких зелених барвників можливе поєднання азо- і антрахінонових хромофорних структур, однак найчастіше вони представляють собою механічну суміш барвників жовтих і синіх або бірюзових кольорів $[15,16]$. Деякі яскраво-сині відтінки можуть містити суміш антрахінонових, азо- i фталоціанінових барвників.

Отже, у активних барвниках у якості хромофорів найчастіше зустрічаються азогрупи, антрахінонові та рідше - фталоціанінові і формазанові.

Таким чином, активні барвники ковалентно зв'язуються 3 функціональними групами макромолекул целюлозних волокон, утворюючи з ними єдину хімічну сполуку. Забарвлення активними барвниками на волокнистих матеріалах відрізняються високою стійкістю до прання і значно перевищують даний показник для інших класів, які взаємодіють з макромолекулами волокон за рахунок водневих ван-дер-ваальсових або іонних зв'язків.

У зв'язку з появою активних барвників природно виникло питання про те, як впливає ковалентний зв'язок барвника 3 полімером на світлостійкість забарвлення, оскільки це має важливе як теоретичне значення, яке полягає у виявленні ролі природи зв'язку барвник - полімер, так і практичну цінність, зокрема при вирішенні проблеми світлостабілізації забарвлень. Аналіз ранніх робіт, присвячених цьому питанню [17-21], показує, що ковалентний зв'язок барвник - полімер істотно не впливає на світлостійкість забарвлень. Більший вплив на стійкість до дії світла при цьому мають хімічна будова барвників, їх стан в полімерному субстраті, хімічна і фізична структура полімеру, умови опромінення та інші фактори. Однак слід зазначити, що вказані роботи відносяться до досліджень монофункціональних активних барвників. 3 розвитком хімії барвників 3'явились нові бі- та навіть поліфункціональні активні барвники. Аналіз літературних джерел свідчить, що комплексні дослідження світлостійкості забарвлень цими барвниками відсутні.

\section{Формулювання мети дослідження}

Метою роботи було дослідження впливу хімічної будови активних барвників, а саме: хімічної структури хромофору, кількості та типу активних груп - на світлостійкість отриманих на бавовняному трикотажі забарвлень. 
Викладення основного матеріалу дослідження

У роботі дослідження здійснені з використанням активних барвників, основні характеристики яких представлені у табл. 1.

Таблиця 1

Характеристика активних барвників, які використовувались у роботі

\begin{tabular}{|c|c|c|c|}
\hline Назва барвника за Colour Index & Активна група & Хімічна клас хромофора & Колір \\
\hline \multicolumn{4}{|c|}{ Монофункціональні барвники } \\
\hline Reactive blue 4 & \multirow{3}{*}{ дихлортриазинова } & антрахіноновий & синій \\
\hline Reactive yellow 4 & & азобарвник & жовтий \\
\hline Reactive yellow 2 & & азобарвник & жовтий \\
\hline Reactive blue 19 & \multirow{6}{*}{ вінілсульфонова } & антрахіноновий & синій \\
\hline Reactive orange 125 & & азобарвник & оранжевий \\
\hline Reactive violet 5 & & азобарвник & фіолетовий \\
\hline Colvazol blue CGB & & - & синій \\
\hline Colvazol red CGB & & - & червоний \\
\hline Colvazol yellow CGB & & - & жовтий \\
\hline Reactive blue 5 & \multirow{4}{*}{ монохлортриазинова } & антрахіноновий & синій \\
\hline Reactive blue 15 & & фталоціаніновий & синій \\
\hline Reactive brown 2 & & дисазобарвник & коричневий \\
\hline Reactive violet 2 & & азобарвник металовмісний & фіолетовий \\
\hline \multicolumn{4}{|c|}{ Біфункціональні барвники } \\
\hline Reactive red 195 & \multirow{8}{*}{$\begin{array}{c}\text { монохлортриазинова / } \\
\text { вінілсульфонова }\end{array}$} & азобарвник & червоний \\
\hline Reactive blue 231 & & формазановий & синій \\
\hline Reactive red 222 & & азобарвник & червоний \\
\hline Reactive yellow 145 & & азобарвник & жовтий \\
\hline Reactive blue 222 & & дисазобарник & синій \\
\hline Bezaktiv Cosmos Blue S-C & & - & синій \\
\hline Bezaktiv Cosmos Rot S-C & & - & червоний \\
\hline Bezaktiv Cosmos Gold S-C & & - & жовтий \\
\hline \multicolumn{4}{|c|}{ Поліфункціональні барвники } \\
\hline Novacron Ruby S-3B & & - & червоний \\
\hline Novacron Blue S-R & & - & синій \\
\hline Novacron Yellow S-3R & & - & жовтий \\
\hline
\end{tabular}

3 метою встановлення залежності світлостійкості активних барвників від хімічної будови хромофору та активної групи, а також від кількості реакційноздатних систем у молекулах, було досліджено кінетику фотодеструкції забарвлень бавовняного трикотажного полотна. Зразки текстильних матеріалів були проінсольовані протягом 320 год. на приладі з ртутно-вольфрамовою лампою RF 1201 BS («REFOND») $з$ періодичним визначенням колірних відмінностей забарвлень на колориметрі PCE-TCR 200. Трикотаж переплетення ластик $1+1$ попередньо був підготовлений за одностайною суміщеною технологією та пофарбований активними барвниками за відповідними режимами [22, 23] при концентрації барвників 1\% від маси матеріалу.

Рис. 1 ілюструє кінетику процесу фотодеструкції монофункціональних активних барвників 3 дихлортриазиновою (рис. 1а), вінілсульфоновою (рис. 1б) та монохлортриазиновою (рис. 1в) активними групами. 

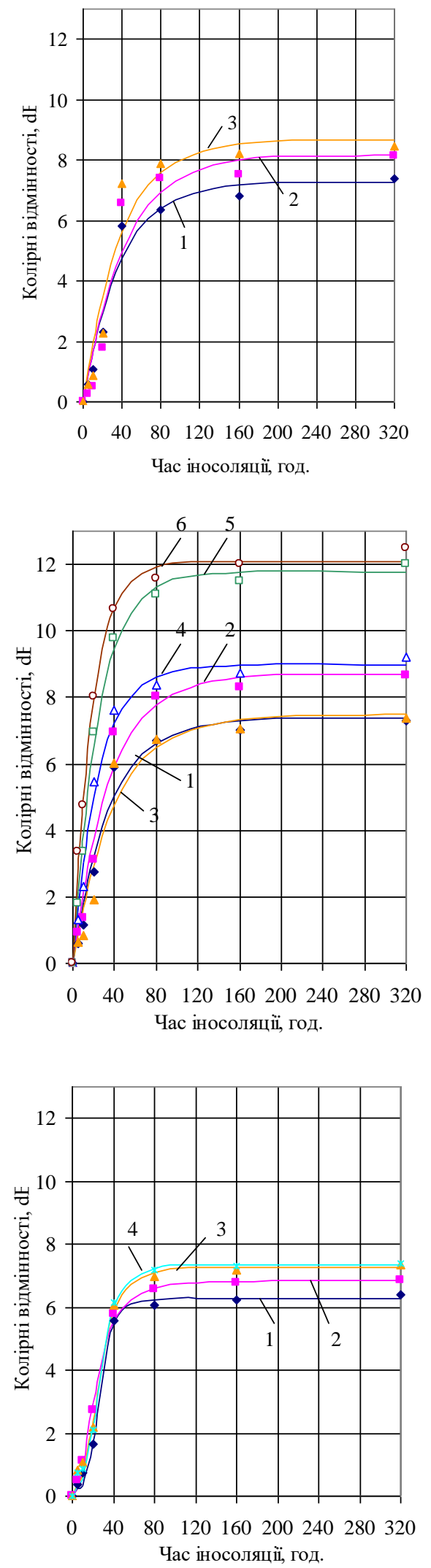

1) Reactive blue 4 :

$$
\begin{gathered}
y=7,273\left(1-e^{-0,026 x}\right), S=0,571, \mathrm{R}=0,986 ; \\
\text { 2) Reactive yellow } 2: \\
y=8,186\left(1-e^{-0,023 x}\right), \mathrm{S}=0,570, \mathrm{R}=0,969 ; \\
\text { 3) Reactive yellow } 4: \\
y=8,667\left(1-e^{-0,026 x}\right), \mathrm{S}=0,527, \mathrm{R}=0,97 .
\end{gathered}
$$

a)

1) Reactive blue 19:

$y=7,380\left(1-e^{-0,029 x}\right), \mathrm{S}=0,493, \mathrm{R}=0,990$;

2) Reactive orange 125 :

$y=8,696\left(1-e^{-0,028 x}\right), \mathrm{S}=0,576, \mathrm{R}=0,990$;

3) Reactive violet 5 :

$y=7,487\left(1-e^{-0,025 x}\right), \mathrm{S}=0,727, \mathrm{R}=0,979$;

4) Colvazol blue CGB:

$y=8,973\left(1-e^{-0,041 x}\right), \mathrm{S}=0,394, \mathrm{R}=0,995$;

5) Colvazol red CGB:

$y=11,764\left(1-e^{-0,041 x}\right), \mathrm{S}=0,355, \mathrm{R}=0,998$;

6) Colvazol yellow CGB:

$y=12,081\left(1-e^{-0,054 x}\right), \mathrm{S}=0,297, \mathrm{R}=0,999$.

б)

1) Reactive blue 5 :

$$
\begin{gathered}
y=\frac{464246,180+6,259 \cdot \mathrm{x}^{4,444}}{1865270,414+\mathrm{x}^{4}, 444}, \mathrm{~S}=0,272, \mathrm{R}=0,998 ; \\
\text { 2) Reactive blue } 15: \\
y=\frac{363,792+6,871 \mathrm{x}^{2,503}}{2492,704+\mathrm{x}^{2,503}}, \mathrm{~S}=0,219, \mathrm{R}=0,998 ;
\end{gathered}
$$

3) Reactive brown 2 :

$y=\frac{14045,390+7,273 \cdot x^{3,242}}{39142,814+\mathrm{x}^{3,242}}, \mathrm{~S}=0,379, \mathrm{R}=0,996$;

4) Reactive violet 2 :

$y=\frac{38852,047+7,357 \cdot \mathrm{x}^{3,565}}{118832,773+\mathrm{x}^{3,565}}, \mathrm{~S}=0,321, \mathrm{R}=0,997$.

B)

Рис. 1. Кінетика фотодеструкції забарвлень бавовняного трикотажу монофункціональними активними барвниками: а) 3 дихлортриазиновою активною групою; б) з вінілсульфоновою активною групою; в) 3 монохлортриазиновою активною групою

Отримані залежності (рис. 1) кінетики фотодеструкції забарвлень показують, що серед досліджуваних активних барвників найбільшу схильність до втрати кольору мають барвники 3 
вінілсульфоновою активною групою. Показники колірних відмінностей вказаних барвників після 320 год. інсоляції коливаються в межах 7,3-12,5 од. В цей час дихлортриазинові та монохлортриазинові барвники демонструють вищу стійкість до дії світла, що становить 7,4-8,5 та 6,4-7,4 од. відповідно.

На графіку рис. 2 наведені результати дослідження кінетики фотодеструкції бавовняного трикотажу, пофарбованого біфункціональними активними барвниками 3 монохлортриазиновою / вінілсульфоновою активною групою.

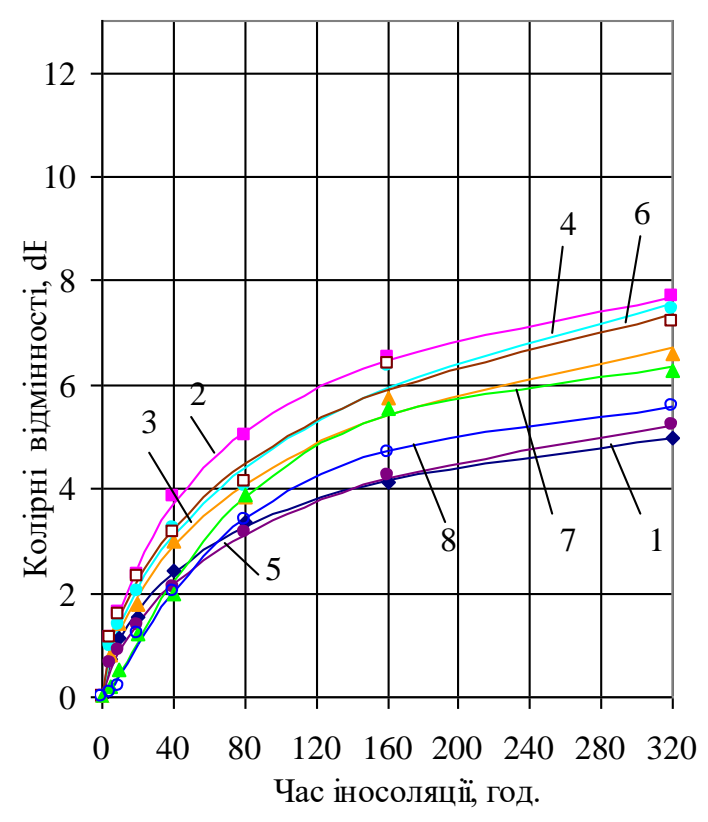

1) Reactive red 195 :

$$
\begin{aligned}
& y=\frac{0,250+6,900 \cdot \mathrm{x}^{0,756}}{30,476+\mathrm{x}^{0,756}}, \mathrm{~S}=0,076, \mathrm{R}=0,999 \text {; } \\
& \text { 2) Reactive blue } 231 \text { : } \\
& y=\frac{0,553+10,394 \mathrm{x}^{0,793}}{33,718+\mathrm{x}^{0,793}}, \mathrm{~S}=0,126, \mathrm{R}=0,999 \text {; } \\
& \text { 3) Reactive red 222: } \\
& y=\frac{0,977+10,288 \cdot \mathrm{x}^{0,759}}{45,220+\mathrm{x}^{0,759}}, \mathrm{~S}=0,220, \mathrm{R}=0,997 \text {; } \\
& \text { 4) Reactive yellow } 145 \text { : } \\
& y=\frac{1,101+12,933 \cdot \mathrm{x}^{0,722}}{45,682+\mathrm{x}^{0,722}}, \mathrm{~S}=0,259, \mathrm{R}=0,997 \text {; } \\
& \text { 5) Reactive blue 222: } \\
& y=\frac{1,048+7,856 \cdot \mathrm{x}^{0,801}}{50,833+\mathrm{x}^{0,801}}, \mathrm{~S}=0,065, \mathrm{R}=0,999 \text {; } \\
& \text { 6) Bezaktiv Cosmos Rot S-C: } \\
& y=\frac{1,051+12,826 \mathrm{x}^{0,668}}{34,908+\mathrm{x}^{0,668}}, \mathrm{~S}=0,296, \mathrm{R}=0,996 \text {; } \\
& \text { 7) Bezaktiv Cosmos Blue S-C: } \\
& y=\frac{15,106+7,152 \cdot x^{1,403}}{402,391+x^{1,403}}, \mathrm{~S}=0,140, \mathrm{R}=0,999 \text {; } \\
& \text { 8) Bezaktiv Cosmos Gold S-C: } \\
& y=\frac{-11,684+6,344 \cdot x^{1,304}}{254,873+x^{1,304}}, S=0,138, R=0,999 .
\end{aligned}
$$

Рис. 2. Кінетика фотодеструкції забарвлень бавовняного трикотажу біфункціональними активними барвниками з монохлортриазиновою / вінілсульфоновою активними групами

Забарвлення, отримані при фарбуванні біфункціональними активними барвниками 3 монохлортриазиновою/ вінілсульфоновою активними групами, демонструють стійкість до дії світла вищу, ніж монофункціональні барвники. При цьому колірні відмінності забарвлень за 320 год. дії світла сягають значень у діапазоні 4,9-7,6 од.

Графіки на рис. 3 демонструють результати вивчення кінетики фотодеструкції бавовняного трикотажу, пофарбованого поліфункціональними активними барвниками марки Novacron, які мають три активні групи.

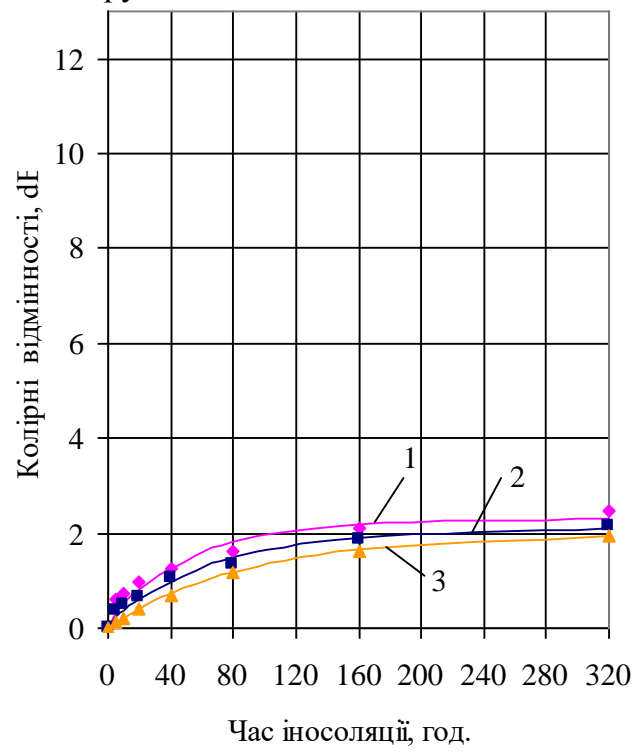

1) Novacron Ruby S-3B:

$y=2,150\left(1,072-e^{-0,018 x}\right), \mathrm{S}=0,206, \mathrm{R}=0,974$;

2) Novacron Blue $S-R$ :

$y=2,037\left(1,041-e^{-0,014 x}\right), \mathrm{S}=0,108, \mathrm{R}=0,993$;

3) Novacron Yellow S-3R:

$y=2,007\left(1,004-e^{-0,011 x}\right), \mathrm{S}=0,016, \mathrm{R}=0,999$.

Рис. 3. Кінетика фотодеструкції забарвлень бавовняного трикотажу поліфункціональними активними барвниками 
Результати вивчення кінетики фотодеструкції поліфункціональних активних барвників марки Novacron свідчать про те, що отримані забарвлення характеризуються високими показниками стійкості до дії світла. Колірні відмінності $\mathrm{dE}$ забарвлень після 320 год. інсоляції становлять лише 1,9-2,4 од. Але необхідно відмітити, що клас цих барвників складається тільки 3 представленої тріади, отримані забарвлення при цьому мають тьмяні відтінки, що обмежує їх застосування з метою отримання яскравих кольорів волокнистих матеріалів.

На діаграмі рис. 4 представлені комплексні результати дослідження впливу хімічної будови хромофору досліджуваних моно- та біфункціональних активних барвників з урахуванням типу активної групи на колірні відмінності забарвлень, яких вони досягають після 320 год. інсоляції.

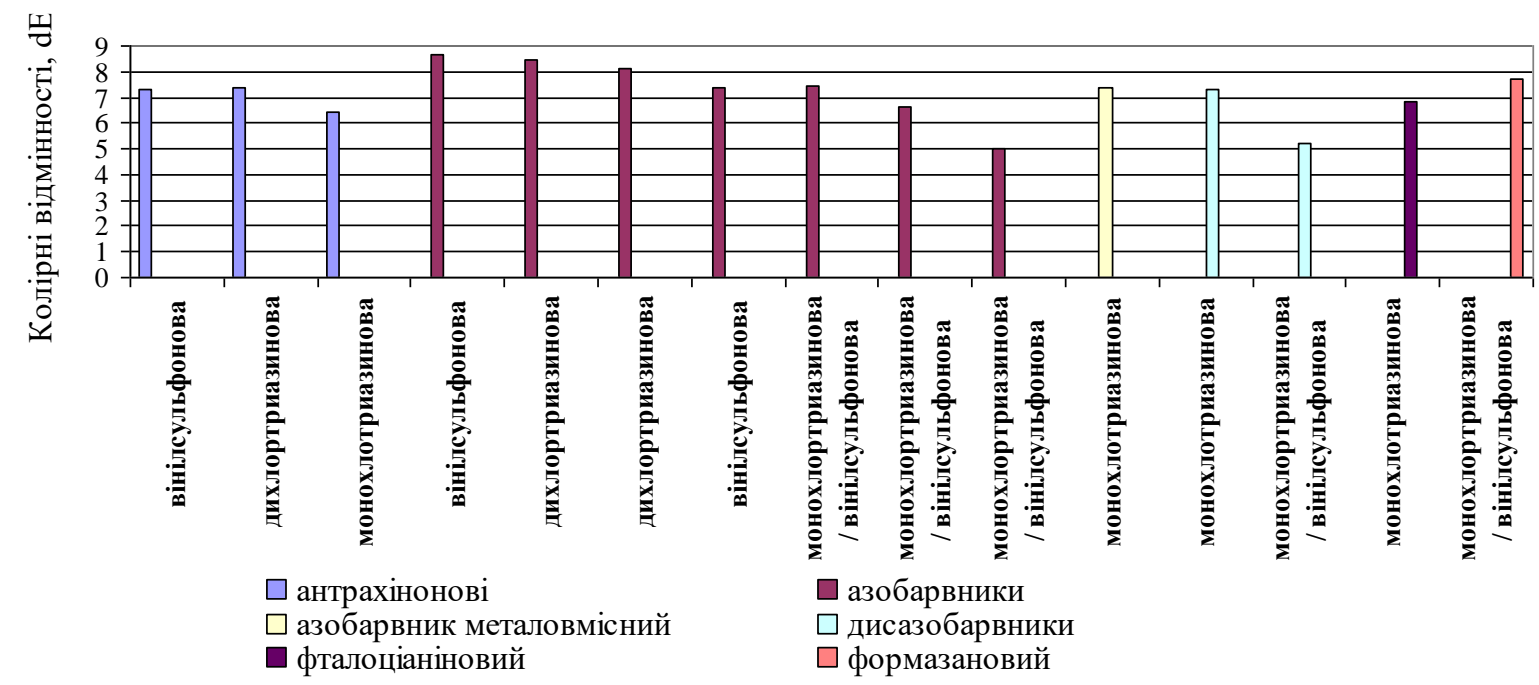

Рис. 4. Вплив хімічної будови моно- та біфункціональних активних барвників на колірні відмінності забарвлень бавовняного трикотажу після 320 год. інсоляції

Аналіз представлених даних (рис. 4) показує, що хімічна будова хромофора активних барвників впливає на світлостійкість забарвлень. При цьому азобарвники незалежно від хімічної будови активної групи мають найнижчу стійкість до дії світла, в порівняння з іншими досліджуваними хромофорними системами. Про це свідчать високі показники колірних відмінностей забарвлень бавовняного трикотажу у кожній групі досліджуваних активних систем.

Діаграма рис. 5 демонструє результати дослідження впливу хімічної будови активних груп монофункціональних активних барвників на колірні відмінності забарвлень після 320 год. дії світла.

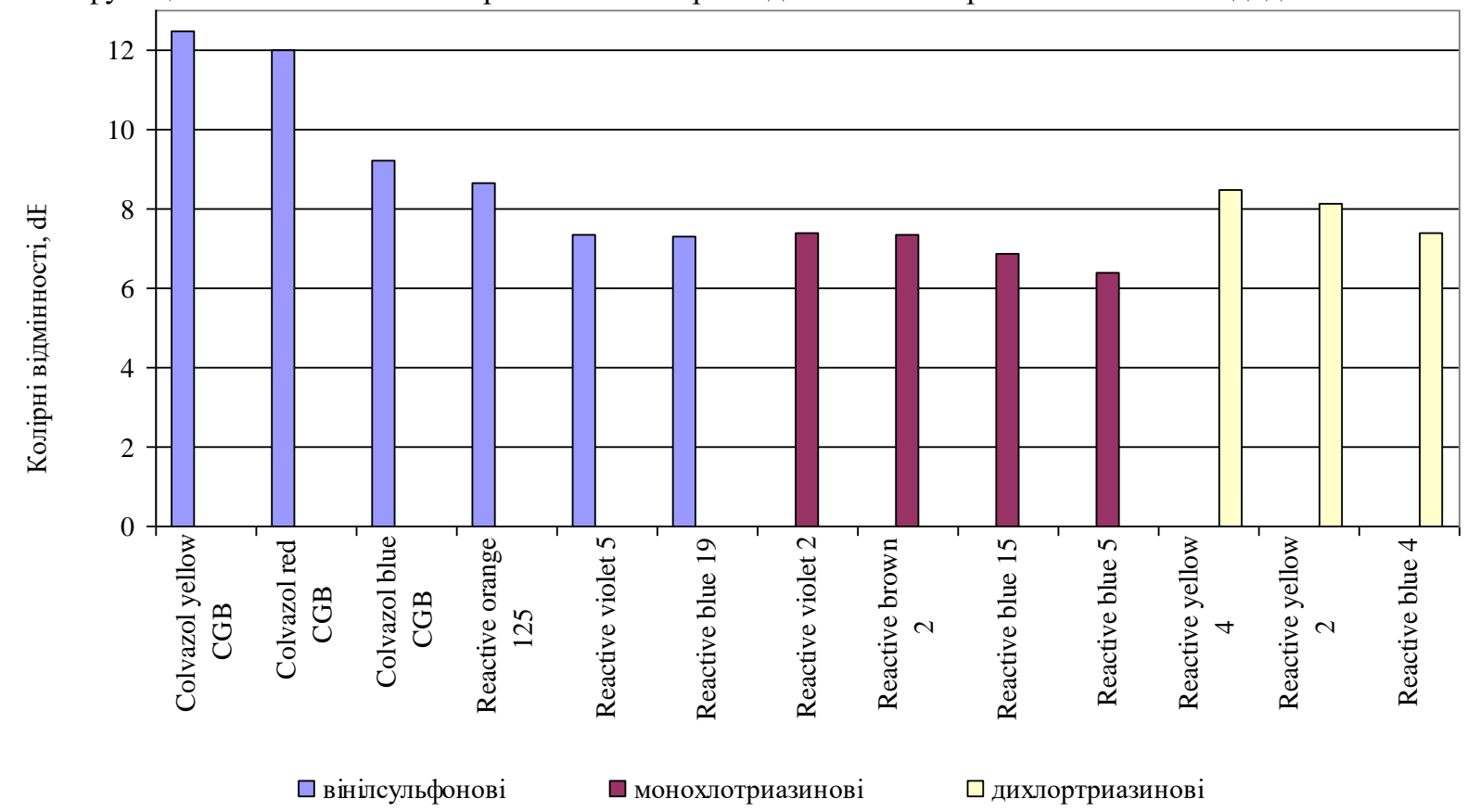

Рис. 5. Вплив хімічної будови активних груп монофункціональних активних барвників на колірні відмінності забарвлень бавовняного трикотажу після 320 год. інсоляції 
Отримані результати (рис. 5) показують, що серед активних барвників 3 однією активною групою найменшою стійкістю до дії світла характеризуються вінілсульфонові активні барвники. Колірні відмінності забарвлень, отриманих з їх використанням, після дії світла протягом 320 год. складають 7,312,5 од. Найбільша стійкість до дії світла спостерігається у забарвлень активними барвниками 3 монохлортриазиновою активною групою. Колірні відмінності забарвлень при цьому досягають лише 6,47,4 од. За отриманими даними дихлортриазинові активні барвники за стійкістю до дії світла займають проміжне положення між вінілсульфоновими та монохлортриазиновими. Колірні відмінності забарвлень 3 використанням дихлортриазинових барвників досягають значень 7,4-8,5 ум. од.

Отже, на основі отриманих результатів дослідження кінетики фотодеструкції монофункціональних активних барвників за стійкістю до дії світла в залежності від хімічної будови активної групи їх можна розмістити у наступний ряд: монохлортриазинові > дихлортриазинові > вінілсульфонові.

На рис. 6 наведені комплексні дані щодо фотодеструкції забарвлень активними барвниками за 320 год інсоляції в залежності від типу і кількості реакційних груп.

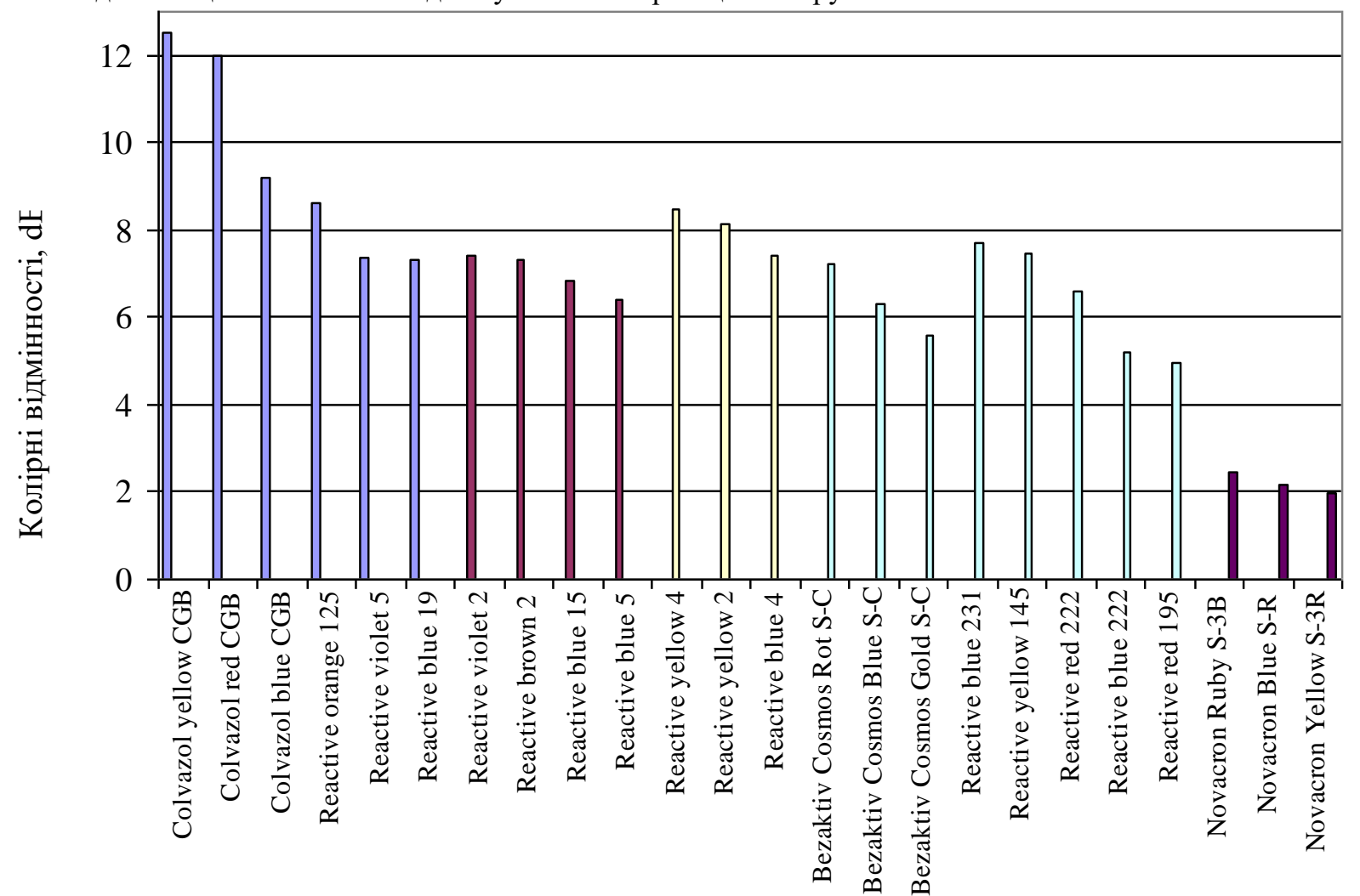

$\square$ вінілсульфонові

$\square$ біфункціональні

\section{монохлотриазінові}

п поліфункціональні

\section{$\square$ дихлортриазінові}

Рис. 6. Вплив хімічної будови та кількості активних груп активних барвників на колірні відмінності забарвлень бавовняного трикотажу після 320 год. інсоляції.

Отримані дані (рис. 6) свідчать про те, що найнижча світлостійкість у барвників з однією активною групою незалежно від ії хімічної будови. Збільшення кількості активних груп позитивно впливає на світлостійкість забарвлень бавовняного трикотажу. Так найвищою стійкістю до дії світла характеризуються поліфункціональні барвники марки Novacron, які мають три активні групи. Таким чином, за результатами вивчення показників колірних відмінностей, яких досягають забарвлення після 320 год. дії світла, досліджувані активні барвники за світлостійкістю можна розмістити у ряд за напрямом зменшення: поліфункціональні 3 трьома активними групами > біфункціональні 3 монохлортриазиновою/вінілсульфоновою активною групою > монохлортриазинові > дихлортриазинові > вінілсульфонові.

Діаграма на рис. 6 також дозволяє зробити висновок про вплив кольору забарвлення на світлостійкість бавовняного трикотажу. Аналіз отриманих даних свідчить, що залежності стійкості забарвлень активними барвниками від кольору не прослідковується.

Таким чином, грунтуючись на проведених дослідженнях впливу хімічної будови активних барвників на світлостійкість їх забарвлень, можна зробити висновок, що вирішальним у процесі 
фотодеструкції забарвлень активними барвниками є хімічна будова та кількість активних груп, які безпосередньо вступають у хімічну реакцію з бавовняним волокном. Саме хімічна будова та кількість активних груп даного класу барвників визначають їх реакційноздатність та, як наслідок, умови застосування.

Відомо, що реакційна здатність змінюється в широкому інтервалі не тільки при переході від одного типу барвників до іншого, а й усередині одного типу [7-16, 24]. В роботі [25] відмінність за величиною реакційної здатності у досліджених дихлортриазинових барвників досягала 10-ти разів, у вінілсульфонових - 7-ми разів, а у монохлортриазинових показники реакційної здатності варіювались від $0,02 \cdot 10^{-3}$ до $2,3 \cdot 10^{-3}$ хв. $^{-1}$, тобто відрізнялись на два порядки.

\section{Висновки}

Таким чином, на основі проведених досліджень кінетики фотодеструкції активних барвників, які характеризуються різною будовою хромофорів та активних груп, а також їх кількістю, можна зробити наступні висновки:

- азобарвники мають найнижчу стійкість до дії світла, в порівняння 3 іншими досліджуваними хромофорними системами, незалежно від хімічної будови активної групи;

- досліджувані активні барвники в залежності від хімічної будови активної групи за стійкістю до дії світла можна розмістити у наступний ряд у порядку зменшення світлостійкості: поліфункціональні 3 трьома активними групами > біфункціональні з монохлортриазиновою / вінілсульфоновою активною групою > монохлортриазинові > дихлортриазинові > вінілсульфонові.

- залежність стійкості забарвлень досліджуваними активними барвниками від кольору не прослідковується, оскільки будова кожної окремої молекули барвників обумовлена одночасно будовою хромофору та активної групи.

\section{Список використаної літератури}

1. Oakes J. Photofading of textile dyes / J. Oakes // Review of Progress in Coloration and Related Topics. - 2001. - Vol. 31. - P. 21-28.

2. Степанов Б.И. Введение в химию и технологию органических красителей / Б.И. Степанов. - М.: Химия, 1984. - 592 с. dyes.

3. Reactive dyes. [Електронний ресурс]. - Режим доступу: http://www.worlddyevariety.com/reactive-

4. Бяльский А.Л. Красители для текстильной промышленности. Колористический справочник / А.Л. Бяльский, В.В. Карпов. - М.: Химия, 1971. - 312 с.

5. Chakraborty J.N. Fundamentals and practices in colouration of textiles / J.N. Chakraborty. - New Delhi: Woodhead Publishing India Pvt. Ltd., 2010. - 433 p.

6. Кричевский Г.Е. Химическая технология текстильных материалов. В 3-ех томах. Т. 2. Колорирование текстильных материалов / Г.Е. Кричевский. - М.: Издательство МГУ, 2001. - 540 с.

7. Кричевский Г.Е. Физико-химические основы применения активных красителей / Г.Е. Кричевский. - М.: Легкая индустрия, 1977. - 264 с.

8. Fiber Reactive Dyes and Cibacron $\mathrm{F}$ in particular. [Електронний ресурс]. - Режим доступу: http://216.146.208.41/tan/tan_fiberreactives.html.

9. The Theory of Coloration of Textiles: [monograph]. Edited by A. Johnson. - Published by the Society of Dyers and Colourists, 1989. - 564 p.

10. Sigrist G. Optimirung der Reaktivfarberei von Cellulosefasern / G. Sigrist, M. Haelters // Melliand Textilber. - 1979. -Vol. 60, Issue 7. - P. 590-594.

11. Antram R.J. Dung-stain (penstain) of wool and its effect on dyed colour and photofading / R.J. Antram, W.R. Regnault, G.A. Wickham // New Zealand Journal of Agricultural Research. - 1992. -Vol. 35, Issue 3. - P. 269-276. doi: 10.1080/00288233.1992.10427504.

12. Bandara J. Fast kinetic spectroscopy, decoloration and production of $\mathrm{H}_{2} \mathrm{O}_{2}$ induced by visible light in oxygenated solutions of the azo dye Orange II / J. Bandara, J. Kiwi // New Journal of Chemistry. - 1999. - Vol. 23. - P. 717-724. doi: 10.1039/A902425E.

13. Taylor J.A. Recent developments in reactive dyes / J.A. Taylor // Review of Progress in Coloration and Related Topics. - 2000. - Vol. 30. - P. 93-108.

14. Степанян А.А. Фталоцианиновые пигменты / Степанян А.А., Бернашевский Н.В., Кулыгина 3.П., Исак А.Д. // Вісник Східноукраїнського національного університету імені Володимира Даля. - 2014. - № 9 (216). - С. 39-49. $464 \mathrm{c}$.

15. Химия синтетических красителей. Том VI: [под ред. К. Венкатарамана]. - Л.: Химия, 1977. -

16. Карпов В.В. Активные красители. Особенности химического строения и способов применения / В.В. Карпов // Рынок легкой промышленности. - 2006. - № 47. - С. 67-71. 
17. Oster G. Fluorescence quenching by nucleic acids / G. Oster // Transactions of the Faraday Society. 1951. - Vol. 47. - P. 660. doi:10.1039/tf9514700660.

18. Oster G. Long-Lived States in Photochemical Reactions. I. Photoreduction of Eosin / G. Oster, A.H. Adelman // Journal of the American Chemical Society. - 1956. - Vol.78(5). - P. 913-916. doi:10.1021/ja01586a012.

19. Кричевский Г. Светостойкость окрашенных текстильных изделий / Г. Кричевский, Я. Гомбкете. - М.: Легкая индустрия, 1975. - 167 с.

20. Махвеладзе Н.Г. О роли свободных радикалов в процессах фотодеструкции азокрасителей на полиамидном материале / Н.Г. Махвеладзе, Г.Е. Кричевский // Журнал прикладной спектроскопии. 1984. - T. 57, №6. - C. 1331-1335.

21. Новорадовский А.Г. Кинетическое исследование ускоренного выцветания смесей красителей / А.Г. Новорадовский, А.М. Штерн, В.М. Анисимов, Г.Е. Кричевский // Журнал прикладной спектроскопии. - 1988. - Т.48, №4. - С. 667-671.

22. Лабораторный практикум по химической технологии текстильных материалов: [под ред. Г.Е. Кричевского]. - Москва: Росс. заоч. ин-т. текстильной и легкой промышленности, 1995. - 414 с.

23. Отделка хлопчатобумажных тканей. В 2 ч. Ч.1. Технология и ассортимент хлопчатобумажных тканей: справочник [под ред. Мельникова Б.Н.]. - М.: Легпромбытиздат, 1991. - 432 с.

24. Колонтаров И.Я. Свойства и методы применения активных красителей / И.Я. Калонтаров // Душанбе: Дониш, 1970. -204 с.

25. Agarwal D. Application of heterobifunctional reactive dyes on silk / D. Agarwal, K. Sen, M.L. Gulrajani // Journal of the Society of Dyers and Colourists. - 1996. - Vol. 112(1). - P. 10-16. doi:10.1111/j.1478-4408.1996.tb01748.x.

\section{References}

1. Oakes J. (2001). Photofading of textile dyes. Review of Progress in Coloration and Related Topics, vol. 31, p. 21-28.

2. Stepanov B.I. (1984). Vvedeniye v khimiyu i tekhnologiyu organicheskikh krasiteley [Vvedeniye v khimiyu i tekhnologiyu organicheskikh krasiteley]. Moscow, Russia: Khimiya [in Russian].

3. Reactive dyes. Retrieved from http://www.worlddyevariety.com/reactive-dyes.

4. Byal'skiy A.L., Karpov V.V. (1971). Krasiteli dlya tekstil'noy promyshlennosti. Koloristicheskiy spravochnik [Krasiteli dlya tekstil'noy promyshlennosti. Koloristicheskiy spravochnik]. Moscow, Russia: Khimiya [in Russian].

5. Chakraborty J.N. (2010). Fundamentals and practices in colouration of textiles. New Delhi, India: Woodhead Publishing India Pvt. Ltd.

6. Krichevsky G.E. (2001). Chemical technology of textile materials. In 3 volumes. Vol. 2. Coloring of textile materials [Khimicheskaya tekhnologiya tekstil'nykh materialov. V 3-yekh tomakh. T. 2. Kolorirovaniye tekstil'nykh materialov]. Moscow, Russia: Publishing house of Moscow State University [in Russian].

7. Krichevsky G.E. (1977). Physicochemical basis for the use of active dyes [in Russian]. Moscow, Russia: Light industry [in Russian].

8. Fiber Reactive Dyes and Cibacron $F$ in particular. Retrieved from http://216.146.208.41/tan/tan_fiberreactives.html.

9. The Theory of Coloration of Textiles: [monograph]. Edited by A. Johnson. (1989). Published by the Society of Dyers and Colourists.

10. Sigrist G., Haelters M. (1979). Optimirung der Reaktivfarberei von Cellulosefasern. Melliand Textilber, vol. 60, issue 7, p. 590-594.

11. Antram R.J., Regnault W.R., Wickham G.A. (1992). Dung-stain (penstain) of wool and its effect on dyed colour and photofading. New Zealand Journal of Agricultural Research, vol. 35, issue 3, p. 269-276. doi: 10.1080/00288233.1992.10427504.

12. Bandara J., Kiwi J. (1999). Fast kinetic spectroscopy, decoloration and production of $\mathrm{H} 2 \mathrm{O} 2$ induced by visible light in oxygenated solutions of the azo dye Orange II. New Journal of Chemistry, vol. 23, p. 717-724. doi: 10.1039/A902425E.

13. Taylor J.A. (2000). Recent developments in reactive dyes. Review of Progress in Coloration and Related Topics, vol. 30, p. 93-108.

14. Stepanyan A.A. Bernashevsky N.V., Kulygina Z.P., Isak A.D. (2014). Phthalocyanine pigments. Bulletin of the Volodymyr Dahl East Ukrainian National University, no 9 (216), p. 39-49 [in Russian].

15. Chemistry of synthetic dyes. Volume VI. Ed. By K. Venkataraman [Khimiya sinteticheskikh krasiteley. Tom VI]. (1977). Leningrad, Russia: Chemistry [in Russian].

16. Karpov V.V. (2006). Active dyes. Features of the chemical structure and methods of application [Aktivnyye krasiteli. Osobennosti khimicheskogo stroyeniya i sposobov primeneniya]. Light Industry Market, no. 47, s. 67-71 [in Russian]. 
17. Oster G. (1951). Fluorescence quenching by nucleic acids. Transactions of the Faraday Society, vol. 47, p. 660. doi:10.1039/tf9514700660.

18. Oster G., Adelman A.H. (1956). Long-Lived States in Photochemical Reactions. I. Photoreduction of Eosin. Journal of the American Chemical Society, vol.78(5), p. 913-916. doi:10.1021/ja01586a012.

19. Krichevsky G., Gombkete J. (1975). Light resistance of colored textile products [Svetostoykost' okrashennykh tekstil'nykh izdeliy]. Moscow, Russia: Light industry [in Russian].

20. Makhveladze N.G., Krichevsky G.E. (1984). On the role of free radicals in the processes of photodegradation of azo dyes on polyamide material [O roli svobodnykh radikalov $\mathrm{v}$ protsessakh fotodestruktsii azokrasiteley na poliamidnom materiale]. Journal of Applied Spectroscopy, vol. 57, no. 6, s. 1331-1335 [in Russian].

21. Novoradovsky A.G., Stern A.M., Anisimov V.M., Krichevsky G.E. (1988). Kinetic study of accelerated fading of mixtures of dyes [Kineticheskoye issledovaniye uskorennogo vytsvetaniya smesey krasiteley]. Journal of Applied Spectroscopy, vol.48, no. 4, s. 667-671 [in Russian].

22. Laboratory workshop on chemical technology of textile materials: ed. by G.E. Krichevsky [Laboratornyy praktikum po khimicheskoy tekhnologii tekstil'nykh materialov]. (1995). Moscow, Russia: Ross. correspondence course in-t. textile and light industry [in Russian].

23. Finishing of cotton fabrics. At $2 \mathrm{pm}$. Part 1. Technology and assortment of cotton fabrics: a reference book. [Otdelka khlopchatobumazhnykh tkaney. V 2 ch. CH.1. Tekhnologiya i assortiment khlopchatobumazhnykh tkaney: spravochnik]. Ed. by Melnikov B.N. (1991). Moscow, Russia: Legprombytizdat [in Russian].

24. Kolontarov I.Ya. (1970). Properties and methods of using active dyes [Svoystva i metody primeneniya aktivnykh krasiteley]. Dushanbe, Tajikistan: Donish, [in Russian].

25. Agarwal D., Sen K., Gulrajani M.L. (1996). Application of heterobifunctional reactive dyes on silk. Journal of the Society of Dyers and Colourists, vol. 112(1), p. 10-16. doi:10.1111/j.1478-4408.1996.tb01748.x. 